\title{
Green Wireless Networking
}

\author{
Prachi \\ Associate Professor \\ CSE \& IT \\ ITM University \\ Gurgaon ,India
}

\author{
Nisha \\ MTech Students \\ CSE \& IT \\ ITM University \\ Gurgaon ,India
}

\author{
Suruchi \\ MTech Students \\ CSE \& IT \\ ITM University \\ Gurgaon ,India
}

\begin{abstract}
Now days, energy consumption in conniving of mobile wireless network is very important research topic due to its pervasive ingress and large potential consumption. For that reason, effective solutions are needed for the green wireless networks i.e. power cutback wireless network because of its obligatory drift. In this paper, the foremost abridge the grade worn in the citations for concert conduct. After that, accent on recounting the approach anticipated by exposition a good quality of reference from documentation. The chief investigate administration are : the innate rank research, where the attempt are principally centralized on the supremacy loudspeaker segment; the unit blueprint alteration together with the cell-breathing performance and exposure add-on methods like femto cells and relay; in totting up, also encompass the walkie-talkie store supervision and the cognitive walkie-talkie. These tactic are scrutinize, equate, open and next a shell of sorting and combination is planned. At last, narration a few coopetition projects committed for this area.
\end{abstract}

\section{Keywords}

energy efficiency; green walkie-talkie; wireless network.

\section{INTRODUCTION}

The unrelenting world of wireless networks providing high speed internet usage to end-users as well as the popularity of iPhone and last type of gadgets has surely increased the traffic demand, resulting in stimulating fair evolution of net infrastructures and swift hike of power needs. Consequently, it becomes necessary for itinerant movers to preserve viable enlargement and, at the equivalent time, restrict the power cost.

\subsection{Green Evolution}

1. The amount of power expenditure in wireless net results a major threats for environmental protection, feasible enlargement and ICT (Information Communication Technologies) due to increase of greenhouse gas ejection. It should be noted that the ICT Market grant $3 \%$ of universal Greenhouse Gases (CO2) ejection. This percentage resolves hastily if no prompt methods are engaged. The initial complication of the majestic power utilation is the usage of remnant oil (e.g. diesel), which induce immeasurable GHG (Green House Gases). Some statistics showing the effect of energy consumption in ICT are:In USA, the inhabited ICT bazaar requisite $2 \%$ of the entirety power shaped in $2005[\underline{3}, \underline{4}]$.

2. In Italy, the telecom consumed around entirely Italian power fabrication $[\underline{2,3]}$.

3. Similarly France Telecom has consumed around $0.4 \%$ of the power assembly of the complete countryside [3, 4].
However, the enormous request of energy is mainly from the radio access network (RAN), which contributes $56.6 \%$ of the power utilization of a cellular net (see Figure 1).

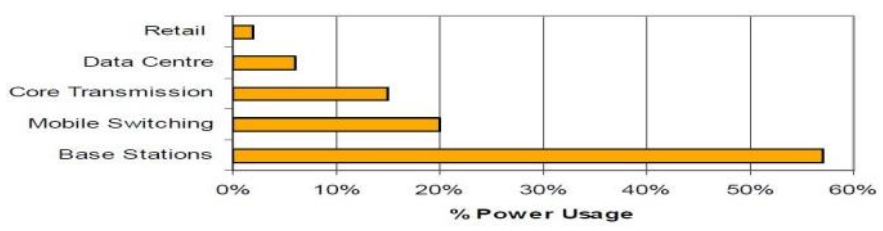

Fig 1: Cellular Network Power Consumption

The key reasons for elevated power utilization of RAN are:

1. The uneconomical energy deliver transmutation interested in diffusion by base station (BS) systems, in which the RF control loudspeaker segment absorbs up to $69 \%$ of the power complete, dispersing astonishingly amount of energy with subject to heat and small part correlating with some other aspects. (see Figure 1 ), presenting a blend of dissimilar source that show the utilization role from dissimilar mechanism.

2. Destruction of a useful $\%$ of energy because of mobile BSs due to the fact that traffic cannot be measured unvarying, neither geologically or temporally. It is notice that for a distinctive walkietalkie entrée arrangement; just $9 \%$ of BSs are liable for a shared of the way, while $45 \%$ of the BSs grip nearly $4.4 \%$ of full amount passage. Pleasing into report this trouble, researchers stare for the solution. (see Figure 2), various energy consumption in the base station is shown.

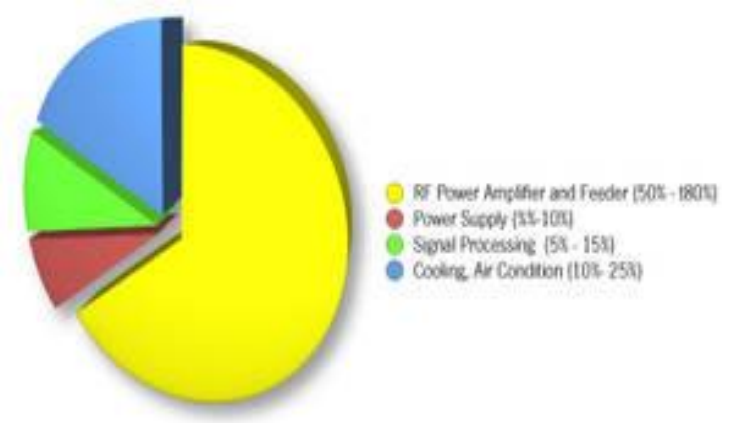

Fig 2: Energy Consumption In The BS.

The Solutions Are:

1. In this the BSs are made to work in sleep mode concepts for wireless base stations where the transmitter power amplifier is off when there is intake of low level data and vice -versa. Switching off the power amplifier can have energy reduction estimated at $10-20 \%$. 
2. The another approach is of using diverse radio base stations, femtocells and multihop relays as compared to networks which consist only of radio base stations. Mathematical analysis states that the use of diverse network can have energy savings of $60-70 \%$.

3. The most efficient technique is to have energy efficient packet scheduling schemes for radio base station data transmission due to which bandwidth expansion (low traffic) and compression (high traffic) techniques can save energy.

4. To perk up the power competence of video transmission techniques. A scheme random net coding is used to make the data transmission more efficient and to reduce delays in transmission saving energy up to $25 \%$.

According to SMART 2020 information the quantity of $\mathrm{CO}_{2}$ owing to ICT was nearly 149.5 of net emission $\mathrm{CO}_{2}$ all through year 2002, in which $42 \%$ was owed to the movable sector, and during 2020 it will grow to 349 of net production $\mathrm{CO}_{2}$, with $50 \%$ of emission from the portable The ethics are additional provided (see Figure 3 ).

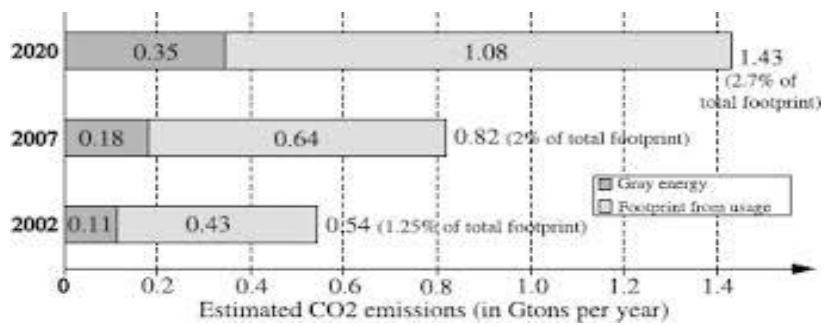

Fig 3: Carbon Footprint For Telecom 2002/2020.

However, many countries have taken measures in saving energy above the globe and intend to enclose a greenhouse gas decline by the following actions:

1. Smart motor systems: China government has guarantee to reduce $10 \%$ of China's emissions $(2 \%$ of global emissions) in 2020 coming from China's motor systems alone and to improve industrial growth even by $10 \%$.

2. Smart logistics: European Union being a leader of proficiency in transport and storage, smart logistics in Europe could deliver fuel, electricity and heating savings up to $20 \%$ greenhouse gas reduction by 2020.

3. Smart buildings: Better conniving of buildings having automation and management system may perhaps hoard $14 \%$ of North America's building emission.

4. Elegant grid: This technology may possibly mainly diminish power utilization by proper monitor and administration of power grid, through designing stylish meter and after that by merging extra superior ICTs into the professed power internet can lessen up to $31 \%$ of GHG discharge in India.

On a whole all the above deeds can be squeeze as the SMART revolution.

1. Standardization: The ICT standardise(S) its approach on provocation of weather change which on the other hand help to have small amount of energy consumption leading to less emission of GHG.
2. Monitoring and Accountability: These two factors help in optimising and setting up key business priority of data resulting in energy efficient usage and less emission too.

3. Rethink and Transformation: It is worn to rethink (R) on how to survive, discover, cooperate and toil in a little carbon financial system, firstly by not only maintain low-level of efficiency, but providing feasible low cost a substitute to high carbon activities. However isolated efficiency doesn't result in an ultimate goal it is operational lucidly jointly, that will have the supreme contact.

4. Transformation: Is achieved when all the above stated factors are standardised leading to the usage of low level carbons across all the sectors of economy

Thus on a whole ICT sector can't work in isolation for its smart implementation, it necessitate the assist of government and erstwhile industry for having safe message of data inside and connecting sector gaining financially simultaneously. Therefore, it is currently up and about to strategy maker, manufacturing cream of the crop and the sector to work in a coherent manner in order to achieve high stake. As well as the load from societal tasks merged as an extra sturdy dynamic strength for wireless operator to vividly lessen power utilization and carbon marks.

\section{RELATED WORK}

The research forwarded in this editorial is certainly not the foremost on this area. The analyses about power competence are somewhat that swiftly grow international due to which there was progressive initiation and speedy attentiveness on the topic. The main works done are:

1. The research work on this area was stamp in the year 2001 where the upcoming green technology wasdiscussed.

2. IEEE has conduct two green significanceworkshops in 2009, in union with ICC'09 plus Globecom'0 at smallest amount and three more in 2010, in union with ICC'10, PIMRC'10, and Globecom'10, correspondingly

3. Furthermore, power alert walkie-talkie and net technology (EARTH), one of the incorporated project beneath European structure Program; start its sphere regular to build up green technology at the opening of 2010.

4. In this paper, emphasis is laid on amalgamate the green wireless net investigate swing and bring to light the panorama and upcoming challenge. The diverse interpretation are mentioned by way of a recounting the universal ideology and traits of every single of them.

\section{COMPOSITION OF ARTICLE}

\subsection{Power effectiveness technique}

3.1.1 Discuss about Metrics for power effectiveness and utilization concert judgment used to measure the power act of system and process.

3.1.2 Unit design adjustment also called as CLA techniques are discussed helping in cheeping energy consumption. It is further subdivided into:

3.1.2.1 Illustrates about the cell shaping algorithms, where energy consumption is minimized by switching off unnecessary BSs depending upon traffic intake as well as 
conformity the size of lasting cell in charge to promise exposure

3.1.2.2 Describes macro/femtocell deployments and their donations in power reduction portion as well less ejection of greenhouse gas.

3.1.3 Describesenergy-efficient transmission methods and RRM.

\subsubsection{Describes CR (cognitive radio).}

3.1.5Describes Component approach

\subsection{Classification of Techniques}

\subsection{Projects}

\subsection{Conclusion}

\subsection{Power effectiveness technique}

\subsubsection{Metrics for power effectiveness and utilization concert judgment}

The global environment issue is growing hastily due to increasingly consumption of energy in each and every sector. Therefore; attention should be paid in reducing energy consumption in order to have a green wireless communications. In this paper a solution i.e. energy efficiency metrics which aims at measuring the performance and study the mechanism of system. It should be noted that energy metrics is considered as the major platform for each and every corner of wireless networks hence it should be discussed deeply keeping in mind each and component, equipments etc. A large number of metrics are defined on the basis of the attribute of energy consumption and efficiency at various levels in wireless networks, some of them are briefly mentioned in [25].There are mainly two types of energyefficiency metric.

1. The first one is correlated to the proportion of secure expediency (e.g. broadcast expanse reach, region roofed, amount produced, bit transmit, etc.) to the preoccupy power/vigour worn.

2. The second one is a power utilization metric engross to the power frenzied per part of protected value.

The main aim of this segment is to abridge the main metrics used in dropping the power effectiveness/utilization of substantial policy and proficiency expected to this source. Various important metrics defined at the section level are describe in the subsequent sector: Firstly, the supremacy loudspeaker competence metric was defined but it doesn't yield good results therefore, there occurs the requirement of other metrics which is the peak-to-average power ratio (PAPR) leading to successful lessening of energy consumption thus having better amplifier efficiency .Secondly , a rich set of metric is defined at access node level for base station energy consumption and derived some useful facts about power utilization ranking (PUR) give the power worn for transmit a portion of data (Joules/bit). Some miscellaneous metrics were also observed which aims at the attained utility of the spectral effectiveness $(\mathrm{b} / \mathrm{s} / \mathrm{Hz})$, the power competence $(\mathrm{b} / \mathrm{s} / \mathrm{Hz} / \mathrm{W})$ [5] and the radio competence $((\mathrm{b} \cdot \mathrm{m}) / \mathrm{s} / \mathrm{Hz} / \mathrm{W})$ [5], measure the data speed transmit and broadcast reserve.

\subsubsection{Unit design adjustment}

In this part, the technique categorized under CLA.These techniques under category of CLA are discussed aim at reducing the network energy consumption by allowing adapt, customize and extend the transportation of the RAN in purpose of spatial and temporal passage distributions.

\subsubsection{Cell shaping techniques}

This technique helps in dropping the power utilization in a cellular net by introducing the switching-off plus cellbreathing schemes.

1. Switching-off Scheme: The main idea is to transmit to the snooze form position, the largely figure of BSs throughout the squat passage stage, without affecting its exposure or facility accessibility by maintaining jamming odds threshold .Onthe other hand, the active cells have got to take accusation of the left over passage, which increases the exposure scope by a maximum BS transmission power and resulting in the maximum coverage radius of cell.

The switching-off along with cell-breathing fiction is classified into two types:

1.1 Switching-off network preparation: In this method, the ratio of deactivate BSs to left over active BSs is intended along with the switching-off period, where passage is consider satisfactorily squat to complete the BS switching-off not violate a jamming possibility edge.

1.2Cell-breathing coordination: In this method, calculations were done from energetic to slumber approach and vice versa in bid to evade disorder of the net for the period of the passage redistributions.

\subsubsection{Macro-femto radio admittance deployments}

It is a procedure that is achieving additional heights into the existing drift. The main enhancement of this scheme is to avoid prologue of fresh macro BSs to enlarge exposure and accessibility by enforcing the capability of a macro cell deployment without a elevated raise of power burning up. The main overhead in this CLA technique is that it augment the femtoBSs mass it might revolve exposed in over-provisioning that might guide the net to amplify the utilization. However, in order to evade this, the utilisation of snooze mode to manage the figure of dynamic femtoBSs, which permit to enlarge the femtoBS mass enforcing exposure stage without a major blow on net power utilization. The imitation reveal that if the femtoBSs are deploy first throughout the year and then, according to desires, macro BSs are additional, it give as conclusion a high-quality scheme of net expansion, since a superior figure of femtoBSs mount at the start of the year reduce the need to mount new macro BSs, which can blow additional drastically the power utilization. In addition, the femtocell resolution helps to surmount inter-cell coordination and intrusion as well.

\subsubsection{Energy efficient transmission methods and $R R M$}

After seeing that CLA methods make up the upper level of energy hoarding on network range, now in this section discussion are carried on techniques which are also be able to donate to energy saving, continuing with transmissions methods that are energy efficient as well as RRM. The study of [4] gives the overview of energy efficient radio methods. 
Numerous approaches are exposed, for instance controlling the power of transmission in which system adjust its level of power in variable's function such as channel condition, other approach attempt to merely utilize restricted information, by exploiting them heuristically or by putting some extra data such as location or direction to neighboring nodes in order to locate most favorable transmission power rates via means of algorithms. Moreover in this reference, some other techniques are also cited like adjustment of packet's size. FEC and ARQ i.e. (forward error correction and automatic repeat request) scheme, avoidance of collision, adjustment of data rate and adaptive modulation, the medium access control (MAC) layer which analyses the point in time as soon as a transmission begins, Logical Link Control (LLC) decide the accurate structure of the packet, e.g. its size moreover what to be done regarding errors.

Starting with energy efficiency on transmission mechanisms, MIMO (multiple-input multiple-output) systems are widely reconsidered by energy-efficiency survey like [7]. In [7], it is made known that MIMO idea (i.e., systems having several antenna terminals) is a vital tool as well as one of the technological burst through in communications. Peer-to-peer communication, via numerous aerial terminals within complete variety manner (i.e., entire satellite dish are exercise in the direction of forwarding the similar information through the medium) diminish the power of transmission and guarantee a good quality of transmission. It revealed the relation among rate of data, power of transmission as well as energy effectiveness for MIMO systems. One more significant matter originates in the energy efficiency methods are linked to RRM.The key scheme is to make most favorable exploitation of transmission resources for e.g. bandwidth, time so as to lessen power utilization. This difficulty should be resolved below a little restriction known by channel situations such as QoS as well as transmission and receiver system features. Study of [8] has put forward the basic structure of four deals which are recognized amongst the most important reserves of movable network: exploiting cost and energy, spectrum and power, bandwidth and energy in addition to delay-energy. In order to determine equilibrium mark for above mention variables never leaving the quality of service, convenience in addition to network exposure is the aim of RRM . There is a call forconstantly getting better the RRM moreover transmission method is present matter of mobile communications so as to better use and balance previously exposed benefits of methods so as to give way energy efficiency at huge extent i.e. femtocells ,relay and cell breathings.

\subsubsection{CR (cognitive radio)}

$\mathrm{CR}$ can be defined as follows "a radio frequency transmitter/receiver that is designed to intelligently detect whether a particular segment of the radiospectrum is currently in use, and to jump into (and out of, if necessary) the temporarily-unused spectrum very rapidly, without interfering with the transmission of other authorized users" [9].Thus ,CR scheme should able to reconfigure their communication factors to regulate as well as compare the channel environment moreover in the similar logic employment of CR for spectrum maximization could employ it to refine energy utilization. At hardware stage, recent technologies are capable to do job by means of diverse transmission factors like modulation sequence, bandwidth, data rate, frequency, power and so on, consisting a broad functioning scope. At present Software Defined Radio (SDR) provides sufficient adjustable and little price in a solitary hardware's portion.CR is basically use solution in favor of enhancing the entire techniques by now discussed. This technique is powerfully linked to RRM furthermore transmission methods because of its capability of observing the channel circumstances moreover building judgment on transmission factors and resources to assign

\subsubsection{Component approach}

One of the most dynamic research is on energy-efficient components so far in this domain, This research comprises the internal BS architecture, inactive components switch-off and component energy efficiency improvement .It is the major apprehension at this stage is RF energy amplifier effectiveness in addition to that, the whole RF transmission efficiency. Study is going on a few recent interior BS structural designs discussed in $[10,11]$, in which an amplifier goes right at the back of every antenna part. Insertion losses are diminished through this design because of the connections of cable .Toptower architectures $[10,11]$ join the digital part to antenna of RF made through optical fibers in order to lessen transmission collapse. Advantage reachable from photonics as well as optical fibers are remarkably burning theme of network research.

\subsection{Classification of Techniques}

Categorize all methods along with suggestion for power competent mobile networks which have been examined subsequently. "Table 2", put forward a broad classification of these suggestions every method is measured in expressions of achieved energy investments moreover output of applying an approach over network development and operation. At last emphasize on some of the research challenges for each of these approaches. After that, these mechanisms and proposals can be combined in structure (see Figure 4)

\begin{tabular}{|c|c|c|}
\hline $\begin{array}{l}\text { (CSS) cell size } \\
\text { Shaping } \\
\text { Techniques } \\
\text { Layer }\end{array}$ & $\begin{array}{l}\text { Cell size sha } \\
\text { techniques }\end{array}$ & eathing and switching-off \\
\hline \multirow{2}{*}{$\begin{array}{l}\text { Coverage } \\
\text { Extension } \\
\text { Technique } \\
\text { Sublayer }\end{array}$} & Femtocell & Relays \\
\hline & Energy-eff & $\begin{array}{l}\text { In method and RRM } \\
\text { e management) }\end{array}$ \\
\hline \multirow{2}{*}{$\begin{array}{l}\text { Environment } \\
\text { Learning and } \\
\text { Information } \\
\text { Exchange } \\
\text { Layer }\end{array}$} & \multicolumn{2}{|c|}{$\begin{array}{l}\text { CR (i.e. cognitive radio) and information exchange } \\
\text { method }\end{array}$} \\
\hline & \multicolumn{2}{|c|}{ Component level improvement } \\
\hline
\end{tabular}

Fig 4:Organization of energy-efficient approaches

Table 1. Classification Of Different Energy Efficient Resources

\begin{tabular}{|l|l|l|l|}
\hline $\begin{array}{c}\text { Research } \\
\text { theme }\end{array}$ & $\begin{array}{c}\text { Energy } \\
\text { savings/ } \\
\text { Improve } \\
\text { ments }\end{array}$ & $\begin{array}{c}\text { Results } \\
\text { on } \\
\text { planning } \\
\text { and } \\
\text { /process } \\
\text { stage }\end{array}$ & Challenges \\
\hline $\begin{array}{l}\text { 1)Cell } \\
\text { breathing } \\
\text { and }\end{array}$ & $\begin{array}{l}\text { Energy } \\
\text { saving } \\
\text { about }\end{array}$ & $\begin{array}{l}\text { Energy } \\
\text { efficien } \\
\text { cy }\end{array}$ & $\begin{array}{l}\text { More work should } \\
\text { be done in the } \\
\text { methods that allow }\end{array}$ \\
\hline
\end{tabular}




\begin{tabular}{|c|c|c|c|}
\hline $\begin{array}{l}\text { switching- } \\
\text { off layout }\end{array}$ & $\begin{array}{l}(25-50) \% \\
\text { according } \\
\text { to } \\
{[12,13,14} \\
]\end{array}$ & $\begin{array}{l}\text { progres } \\
\text { s with } \\
\text { smaller } \\
\text { cells } \\
\text { and } \\
\text { denser } \\
\text { deploy } \\
\text { ments. } \\
\text { Though } \\
\text {,it } \\
\text { enhanc } \\
\text { es } \\
\text { infrastr } \\
\text { ucture } \\
\text { costs } \\
\text { and } \\
\text { launch } \\
\text { solitary } \\
\text { point } \\
\text { breakd } \\
\text { own } \\
\text { nodes. }\end{array}$ & $\begin{array}{l}\text { the management of } \\
\text { distributed/clustered } \\
\text { mechanisms at } \\
\text { large-scale } \\
\text { networks. }\end{array}$ \\
\hline $\begin{array}{l}\text { 2)Macro/fe } \\
\text { mtocells } \\
\text { networks }\end{array}$ & $\begin{array}{l}\text { Energy } \\
\text { investme } \\
\text { nts equal } \\
\text { to } 60 \% \\
{[10]}\end{array}$ & $\begin{array}{l}\text { Offer } \\
\text { granularit } \\
\text { y to } \\
\text { service } \\
\text { provision } \\
\text { and } \\
\text { coverage } \\
\text { by } \\
\text { tailoring } \\
\text { the kind } \\
\text { of contact } \\
\text { device } \\
\text { along } \\
\text { with } \\
\text { resources } \\
\text { to the } \\
\text { genuine } \\
\text { traffic } \\
\text { requirem } \\
\text { ents. }\end{array}$ & $\begin{array}{ll}\text { There are } & \text { open } \\
\text { aspects } & \text { on } \\
\text { coordination } & \text { and } \\
\text { management } & \\
\text { mechanisms to grip } \\
\text { he network } \\
\text { heterogeneity. }\end{array}$ \\
\hline 3) Relays & $\begin{array}{l}\text { Results in } \\
{[16]} \\
\text { illustrate } \\
\text { savings } \\
\text { of about } \\
(5-20 \%)\end{array}$ & $\begin{array}{l}\text { Relays } \\
\text { are useful } \\
\text { as energy } \\
\text { efficient } \\
\text { mechanis } \\
\mathrm{m} \text { only if } \\
\text { the power } \\
\text { used by } \\
\text { relaying } \\
\text { is } \\
\text { satisfacto } \\
\text { rily low. }\end{array}$ & $\begin{array}{l}\text { The requirement of } \\
\text { protocols and } \\
\text { mechanisms to have } \\
\text { helpful methods of } \\
\text { relaying is an open } \\
\text { theme. }\end{array}$ \\
\hline $\begin{array}{l}\text { 4)RRM, } \\
\text { mechanisms } \\
\text { and energy } \\
\text { efficient } \\
\text { transmission }\end{array}$ & $\begin{array}{l}\text { There are } \\
\text { varieties } \\
\text { of } \\
\text { approach } \\
\text { es in this } \\
\text { field. so, } \\
\text { it is } \\
\text { complex } \\
\text { to give a } \\
\text { represent } \\
\text { ative }\end{array}$ & $\begin{array}{l}\text { With } \\
\text { RRM } \\
\text { algorithm } \\
\mathrm{s} \text { and } \\
\text { transmiss } \\
\text { ion } \\
\text { technique } \\
\mathrm{s} \text {, it exist } \\
\text { all times } \\
\text { the } \\
\text { chances }\end{array}$ & $\begin{array}{l}\text { Build up new } \\
\text { mechanisms in view } \\
\text { of the entire diverse } \\
\text { factors isn't simple } \\
\text { theme. And to } \\
\text { discover the best } \\
\text { operation point is a } \\
\text { difficult task }\end{array}$ \\
\hline
\end{tabular}

\begin{tabular}{|c|c|c|c|}
\hline & figure & $\begin{array}{l}\text { of taking } \\
\text { benefit of } \\
\text { trade- } \\
\text { offs. }\end{array}$ & \\
\hline $\begin{array}{l}\text { 5)CR,cognit } \\
\text { ive radio }\end{array}$ & $\begin{array}{l}\text { It is a } \\
\text { device } \\
\text { which } \\
\text { does job } \\
\text { together } \\
\text { with } \\
\text { RRM in } \\
\text { addition } \\
\text { to the } \\
\text { transmiss } \\
\text { ion } \\
\text { methods. } \\
\text { CR is not } \\
\text { easy to } \\
\text { provide a } \\
\text { represent } \\
\text { ative } \\
\text { outline. }\end{array}$ & $\begin{array}{l}\text { The CR } \\
\text { is a } \\
\text { extremely } \\
\text { beneficial } \\
\text { device in } \\
\text { environm } \\
\text { ent it } \\
\text { remove } \\
\text { clash of } \\
\text { concerns } \\
\text { and } \\
\text { informati } \\
\text { on isn't } \\
\text { shared } \\
\text { amongst } \\
\text { nodes }\end{array}$ & $\begin{array}{l}\text { It must carry on the } \\
\text { job on changeability } \\
\text { of software also the } \\
\text { hardware to } \\
\text { advance the } \\
\text { characters which } \\
\mathrm{CR} \text { might fetch to } \\
\text { energy efficient } \\
\text { techniques. }\end{array}$ \\
\hline $\begin{array}{l}\text { 6)Compone } \\
\text { nt approach }\end{array}$ & $\begin{array}{l}\text { The } \\
\text { major } \\
\text { subject is } \\
\text { PA, for } \\
\text { e.g. } \\
\text { Doherty- } \\
\text { Pre- } \\
\text { deformed } \\
\text { ' group } \\
\text { AB. } \\
\text { involves } \\
\text { PA. Up to } \\
\text { 50\% [17, } \\
\text { 15]. }\end{array}$ & $\begin{array}{l}\text { Having } \\
\text { energy } \\
\text { efficient } \\
\text { compone } \\
\text { nts is the } \\
\text { foundatio } \\
\mathrm{n} \text { before } \\
\text { allowing } \\
\text { for the } \\
\text { other } \\
\text { approach } \\
\text { es for } \\
\text { energy } \\
\text { efficient } \\
\text { wireless } \\
\text { networks }\end{array}$ & $\begin{array}{ll}\text { Achieve higher } \\
\text { components } \\
\text { efficiencies }\end{array}$ \\
\hline
\end{tabular}

In the model of categorization and incorporation, a layer arrangement in which top layers require of inferior layers in order to lift their investments. Initially there is component development as a support of the efficiency of energy .Due to this cause, have named (CB) component baseline layer have been named. Improvement on (CB) layer allows slowing down the restriction to assist the design in higher stages. Though, in view of the component approach in terms of way out to all the troubles is rather insufficient to attain major savings. Insignificant quantity of energy is exhausted because of partially efficient resources exploitation, which is still extra significant throughout BS's inactive states. Therefore upper layers are on top of the components. Following layer is (ELIE) i.e. the environment learning along with information exchange layer. In favor of the EL-IE layer, set up of the usual CR's capabilities. This adjustment will allow finding the optimal communication that plans maximum efficiency of energy on RRM stage. These CR methods though shouldn't work unaccompanied leading into explanation of information regarding environs are able to be balanced through the information consolidated via BS neighbors.

Towards the advantage of the preceding layer ,RRM which is energy efficient as well as maximal communication layer is suggested. The resources intended for communication are limited and architect should cautiously locate a equilibrium amongst the power and time delays, spectrum, the energy. An obvious way to improve the communication performance is to 
carry on the exploration in methods similar to MIMO and OFDMA that will authorize to use enhanced their abilities to diminish the power for each bit data.

At last, there is CLA layer. Key method on this stage is the cell-breathing and switching-off method which gives investments on a network range. Setting above mention methods on the top in CSS which is cell size shaping sublayer. A vital matter to talk about is the means in which the organization will be done in varied surroundings. Even if consolidated ways permit to gain an immediate network scene, is somewhat which restrict the expandability and bring in one point failure terminals in the network. This type of coordination method must be then a centre point has to be executed by consumption of supportive accompaniments groups. Those accompaniments in a common group e.g. femtoBS, relay macroBS, etc. are accountable of exposure's region by means of combined aim of increasing a group energy performance pointer. To keep away from clashes with nearby groups to supervise the allocation of group resource and organize supportive communication through varied devices, grouping of methods that exchange information as well as CR are a obvious requirement in order to gain an immediate feedback of surroundings which provides essential information to set up the top activities to acquire.

\subsection{Projects}

Because of significance of this subject there are many combined projects from varied institutions from diverse area, for example research organizations, telecommunications suppliers and universities, are devoted to the power effectiveness associated with wireless networks. Summarized those projects in "Table 2".

Table 2. List Of Projects

\begin{tabular}{|c|c|}
\hline Name of project & Description \\
\hline $\begin{array}{l}\text { 1) The Green Touch } \\
\text { consortium }\end{array}$ & $\begin{array}{l}\text { This is universal huge level } \\
\text { project guided by Alcatel- } \\
\text { Lucent/Bell Labs , Started in } \\
2010 \text { January he involving } \\
\text { period of } 5 \text { years The goal is to } \\
\text { build up the entire structure } \\
\text { required to lessen the present } \\
\text { energy use } \\
\text { networks(ITC).[20] }\end{array}$ \\
\hline 2)ICT EARTH & $\begin{array}{l}\text { It was the structure of } \\
\text { collaboration for a persistent } \\
\text { European Leadership in } \\
\text { Telecommunications guided by } \\
\text { France Telecom, commenced in } \\
2008 \text { June and was ended in } \\
\text { May 2011. [21] }\end{array}$ \\
\hline 3)Mobile VCE & $\begin{array}{l}\text { This project commenced in } \\
\text { 1997, current working phase is } \\
\text { Core 5. Fresh phase } \\
\text { commenced in } 2009 \text { January } \\
\text { with period of } 3 \text { years.[22] }\end{array}$ \\
\hline $\begin{array}{l}\text { 4)Cool Silicon Cluster of } \\
\text { Excellence }\end{array}$ & $\begin{array}{l}\text { This project is guided by } \\
\text { Dresden's technical university, }\end{array}$ \\
\hline
\end{tabular}

\begin{tabular}{|l|l|}
\hline & $\begin{array}{l}\text { It chiefly committed towards } \\
\text { microelectronics progress on } \\
\text { energy efficien mechanism } \\
\text { within ICT domain [18] }\end{array}$ \\
\hline 5)GREENET & $\begin{array}{l}\text { It is a training project to } \\
\text { organize upcoming PhDs in } \\
\text { Efficiency of energy in Green } \\
\text { mobile networks guided by } \\
\text { Catalonia's polytechnic } \\
\text { university [19]. }\end{array}$ \\
\hline 6)BeFemto Project & $\begin{array}{l}\text { It is commenced in January } \\
2010 \text { likely period of 30 } \\
\text { months, is wholly devoted to } \\
\text { technology of femtocells [23]. }\end{array}$ \\
\hline $\begin{array}{l}\text { 7)Energy efficient wireless } \\
\text { networking } \\
\text { (ewin) }\end{array}$ & $\begin{array}{l}\text { Project aim is to give basic } \\
\text { foundation which allow to } \\
\text { diminish energy expenditure } \\
\text { [24] }\end{array}$ \\
\hline
\end{tabular}

\subsection{Conclusion}

This research paper offer a current abstract on green wireless networks research. In this, illustration of all most important worldwide ways, giving a few references in favor of each. along with that projected a categorization of main research theme, examining likely improvements, the results along with the demands of every ways. Visibly these style is not enough and a collective way is essential like offered in the categorization and combination standard. Bunch of extra work is required in every offered layer to attain the significant objectives of energy degradation likely in coming years. With the aim of upcoming research it is believed that this theme have to concentrate on reduction of energy utilization through joining additional approaches. Alternative point of view can too be incorporated like the monetary and price deliberations .In various newest research issues realistic execution, matter of green wireless networks are required rapidly. Significant job is required to build the relation among higher research offers and realistic methods which could be put into practice by workers.

\section{REFERENCES}

[1] U.S. Residential Information Technology Energy Consumption in 2005 and 2010, Final report, prepared by TIAX LLC for U.S. Department of Energy

[2] B Gorjni, ETSI work programme on energy saving. INTELEC 2007. Rome, Italy, 174-181 (2007).

[3] Road map to reduce energy consumption, Green Telco World Congress

[4] U Barth, Alcatel-Lucent, Bell Labs Stuttgart, How To Reduce-Green House Gas Emissions From ICT Equipment, (Slides) Wireless Networks, EARTH research project, ETSI Green Agenda

[5] Liqiang Zhao, Jian Cai, Hailin Zhang, Radio-efficient adaptative modulation and coding: green communication perspective. VTC Spring 2011. Budapest, Hungary, 1-5 (2011) 
[6] H Karl, An overview of energy-efficiency techniques for mobile communication systems. Technical Report, Telecommunication Networks Group, Technical University Berlin (TKN) (2003).

[7] EV Belmega, S Lasaulce, M Debbah, A survey on energy-efficient communications. PIMRC 2010 Workshop. Istambul, Turkey, 289-294 (2010)

[8] Yan Chen, Shunqing Zhang, Shugong Xu, GY $\mathrm{Li}$,Fundamental trade-offs on green wireless networks. IEEE Commun Mag 49(6), 30-37 (2011)

[9] B Fette, Three obstacles to cognitive radio, EE Times design, August 2004.

[10] H Claussen, LTW Ho, F Privit, Effects of joint macrocell and residential picocell deployment on the network energy efficiency. Proc of PIMRC 2008. Cannes, France, $1-6(2008)$

[11] radio techniques to enable energy efficient wireless networks. IEEE Commun Mag (Special Issue: Green Communications) 49(6), 46-54 (2010).
[12] L Chiaraviglio, D Ciullo, M Meo, MA Marsan, Energy aware UMTS access networks. W-GREEN 2008. Lapland, Finland (2008)

[13] MA Marsan, L Chiaraviglio, D Ciullo, M Meo, Optimal energy savings in cellular access networks. Proc ICC Workshops 2009. Dresden, Germany, 1-5 (2009)

[14] Zhisheng Niu, Yiqun Wu, Jie Gong, Zexi Yang, Cell zooming for cost-efficient green cellular networks. IEEE Commun Mag 48(11), 74-79 (2010).

[15] S Vadgama, Trends in green wireless access. Pub FUJITSU Sci Technol J 45(4), 404-408 (2009)

[16] Energy saving performance comparison of coordinated multi-point transmission and wireless relaying. Proc Globecom 2010. Miami, FL, USA, 1-5 (2010).

[17] Opera-Net Project: Optimising Power Efficiency in mobile Radio Networks, (Slides) Celtic Event, Paris, France

[18] Cool-Silicon web page [http://www.cool-silicon.org/]

[19] GREENETwebpage[http://www.fp7greenet.eu/] 